Teaching in Times of COVID-19

Maria Leonor Cadena

Fullerton College 


\begin{abstract}
The world has been turned upside down by this global pandemic, yet some of our institutions expect us to continue teaching the same way. Many of us face major fears, anxiety, social isolation, and financial challenges. I have taken the time to get to know my students to find out what challenges they face and I have developed new ways to reach them during our most isolated times. I have recognized the importance of demystifying STEM fields for our non-traditional students and have attempted to deconstruct the curriculum by exploring layers of power. I make the case that a social justice approach to teaching requires the transformation of ourselves, our curriculum, and our institutions. This pandemic may just be the opportunity for us to do so.
\end{abstract}

Keywords: Pandemic Pedagogy, Teaching STEM, Social Justice, Transformative Teaching, COVID-19 


\section{Teaching in Times of COVID-19}

I got a call from a colleague friend of mine asking me: "Are you going to hold class tomorrow or wait in line to go stock up at Costco?" I was surprised -- not because of the pandemic and its consequences -- but that he would ask me that question. I hadn't even considered the option of abandoning my students in what would be the last class meeting in a semester that seemed to be like the Titanic, sinking after hitting the iceberg. Instead, I set out to develop an informal survey and find out how to better help my (non-online) students transition to emergency "remote instruction," or what really was now online classes. Although students had many fears, including concerns about academic success, most centered on the various aspects of their lives affected by this pandemic. Educators sometimes fail to take into account the many dimensions impacting the lives of students (families, jobs, housing, transportation, and health, to mention a few). Teaching at a community college often entails serving students who face many challenges which lead them to drop out at higher rates than students at traditional four-year institutions. I knew my students would be severely affected, and I needed to figure out a way to help them complete the semester while feeling supported.

Last semester I taught mainly Physical/Biological Anthropology: a class that meets the STEM requirements for graduation. I often call this class "the science class for non-science majors." Over almost two decades of teaching “Introduction to Physical Anthropology," I have noted how most of the students who take this class are non-STEM majors who need to fulfill the Natural Science requirement for graduation to transfer to four-year institutions. I know this based on the questions they ask, and the difficulty they experience learning basic biological concepts. and their difficulty in grasping even what would be considered basic concepts in biology. Because I was one such student, over the years I have developed 
examples to demystify biological concepts. For example, when we talk about protein synthesis, I show the students parts of the documentary Food Inc., and we discuss the importance of food (and the interaction between what we eat and our bodies' biological processes). However, a consequence of this approach is that it takes students much longer to learn such concepts in order to be able to ready to take upper division courses. This may require additional time in tutoring sessions or providing study sessions outside of class for students to ask questions and get individualized instruction. During this pandemic, providing students with individualized instruction and support via Zoom has been a critical part of their learning experience. In some ways, being available remotely has allowed more flexibility, since students can meet with instructors without having to drive to campus. Having Zoom sessions at least once a week in the evening has also proven beneficial for students who work during the day (or have other engagements). I noticed that I get more student participation during sessions held from five to seven pm rather than in the morning sessions. During this pandemic and in these challenging times, being flexible has been essential to the success of many of our students.

Another key component to a social justice approach to teaching is challenging the curriculum and ensuring that we investigate the power structures embedded in systems of knowledge. As my background and academic training is in Cultural Studies, I teach this STEM class within a holistic framework that investigates the politics of science. Throughout the semester, we discuss the biological anthropological study of viruses and we pondered the issues of healthcare in the U.S. and the inequities of access to quality health care. I've seen this within my own family, as my father lost his leg due to lack of medical care (since he was undocumented; eventually leading to his death at the early age of 63). The pandemic has 
provided an opportunity for the students to integrate what they had learned in class about viruses with the sociocultural aspects of events as they were unfolding. We had discussions via online forums about the realities of the pandemic, the way it was affecting communities of color, and the various ways in which this virus has mutated and will likely continue to do so. When physicians make generalization such as "people of color are more likely to get COVID 19 due to their genes," I encourage students to challenge such claims by analyzing the various reasons for this besides genetic determinism (issues like people of color being more likely to work in fields where they are more exposed, industrialized racism, lesser access to healthcare, etc.). I realize the pandemic has provided opportunities for me to encourage more critical thinking while also reflecting on my teaching practices and my pedagogy.

Perhaps the biggest concern many students addressed in my informal survey is their fear of getting or feeling "lost" due to the lack of in-class meetings. By lost I refer to the feeling that some of us might experience when all days seem the same, exacerbated by a lack of structure previously provided by the daily/weekly rituals of attending school. By going to class, students have the ability to interact with each other and get weekly reminders from the professors. Learning from home feels like "every day is Sunday," as one of my students explained. Underprepared students must learn ways to keep themselves organized, disciplined, and focused in school. Many of my students reported that attending in-person classes provides a routine that forces them to be accountable for their readings and learning. This challenges us as instructors to decide whether to hold classes synchronously or asynchronously. Many (if not most) students, however, responded in the survey that they did not want to be expected to attend class lectures synchronously (usually via Zoom). I heard some cite reasons such as lack of reliable internet, not having their own computer or space to be online at home, and even the 
need to go out and get another job (since most students work at least part-time) in order to help support their families. This is when I realized that I needed to practice what Frank Harris III calls "intrusive teaching practices," or maintaining frequent communication with students (Harris, 2020). Consequently, I send students weekly emails, reminders, study guides, and more. I also host virtual office hours via Zoom and Study Sessions before all major exams, where I explain concepts and answer questions. I record all my lectures on YouTube, but I learned that some students prefer to have virtual interactions. At the end of the last semester, I felt that I did as much as I could to help the students survive the effects of this pandemic, which included allowing for late papers and extending extra credit deadlines. I also allowed more make-up exams without requiring verification of an emergency. Yet, I still feel that I could have done better. So, to prepare to teach both Summer and Fall semesters, I decided to delve into as many webinars and books as I could to research best practices in teaching online taking a social justice approach.

This was all happening while juggling major events in my personal life, such as selling my house and moving twice. As a woman of color and a former undocumented immigrant, I feel that I have developed a bit of resilience over the years, yet this pandemic has really affected me as well. I have had days where I have been so depressed and stressed out that I can barely find the strength to even turn on the computer. This makes me realize how difficult this whole process must be for our students, a majority of whom are under-represented minorities and under-prepared. Many are facing issues associated with all the complexities their intersectional identities provoke, such as financial insecurities and fear for their health and their loved ones. This pandemic has affected us all in some similar and different ways, but if I learned anything, it is the importance of being patient, flexible, and tolerant. 
Practicing self-care is essential. Just like the analogy of being in a plane and putting your own mask on first, we must acknowledge our feelings and avoid seeking perfection. I realize that I did my best under the conditions I was facing, and I continue to work hard at practicing cultural humility and reflexivity. I allow myself to be vulnerable with my students and to be honest. This in turn allows them to feel that they too can be open and vulnerable with me (and with each other). We learned that it's okay to make mistakes and we must use these as opportunities for growth. We learned that this pandemic is just a reminder of the importance of being able to adapt to change as part of our human evolution. It has allowed us to re-evaluate our values and priorities and to take care of our loved ones and ourselves. It made me return to spirituality and practice meditation to center and appease my mind, and especially to help cope with my anxiety.

During the summer I taught a course titled "The Anthropology of Magic, Witchcraft, and Religion," which proved to be an excellent opportunity to continue my spiritual search. During this course, I did something I had never done before: I required each student to check in with me at least once via Zoom. I knew this would be a difficult task as I had 140 students in a five-week course and some of them may not have the time or ability to connect via Zoom. As a result, I also gave some students my cell phone number and we talked over the phone. Despite several challenges (and some resistance), the value of this would transcend the many hours I would have to invest. Some students are simply not comfortable talking to instructors as I found out, perhaps it is that power difference that they find intimidating, or perhaps the resistance is based on previous experiences where talking to the teacher meant the student was in trouble. Nevertheless, once we talked, many students said they really benefited from our exchange. I felt I benefited as well from learning more about them and finding how much we 
had in common. This experience gave me the opportunity to really meet each of the students and have a human connection, as well as a mentoring opportunity. It turns out that many of the students were experiencing a thirst for spirituality and connection. Some expressed their feelings of isolation and sense of hopelessness in school or in the pursuit of a degree. This made me realize that we cannot do the basic work of teaching our students if we don't create a connection and relationship where we address the unique needs of each of our students. We need to get to know our students and develop a curriculum that meets their needs at the time, not a filtering system privileging those who have the capital and other resources. When students "fail," we need to investigate what we can do to ensure the system itself is not keeping them from being able to achieve their goals- or worse yet- destroying their goals altogether.

Oftentimes, it is the recognition that the habitus must be reframed in order to manifest social change. French sociologist and philosopher Pierre Bourdieu used this term to describe the ways dominant social and cultural conditions are established and reproduced. For Bourdieu, habitus refers to "a system of internalised structures, schemes of perception, conception, and action common to all members of the same group or class." These "schemes of perception" structure the subject's (shared) world-view (Bourdieu, 1977, p.86). What habitus implies in the context of teaching through the pandemic is our ability to recognize the social, cultural and economic forces impacting our students that produces certain selfperceptions, and then resolving to reach out and connect with them through remote instruction in ways that not only support their struggles, but also help them to understand this "bigger picture." In this connection we can instill in them the notion that they can be successful academically, even in STEM classes where traditionally they might not have done so well. 
Now, more than ever, it is critically important that we communicate to our students that they are not alone, that this pandemic has changed how we do things, and that our basic connection and passion for learning and teaching are very much alive and well. Through altering my teaching practices, I have learned the importance of inspiring and instilling in students the notion that they can revise negative views about themselves in order to have the power to change their lives. This is exactly what allowed me to pursue higher education. It was precisely when a community college professor reached out (through intrusive teaching) and told me she believed I could earn an Associates of Arts degree that I believed it may be possible. My self-perception was changed: a mother of two young children who had dropped out of high school and later college, could dream to earn a college degree, though the odds seemed against me. She became my mentor and taught me to dream about the possibility of achieving my potential, and earning a PhD.

In closing, I find one of the most important qualities teachers can have is the ability to connect with students in a genuine way, to truly care for their wellbeing and get to know them as whole people. My role model has been Dr. Maya Angelou, who declared herself a tough teacher, but one who worked hard and truly cared. I once heard an interview with Angelou where she retold the story of how she met Tupac Shakur, the late singer, songwriter and actor. She told him how important he was, and how many people had sacrificed their lives for him to be in his position today. She went on to declare seeing him - including her students -- as her children. She believed in the importance of empowering them. I was so inspired to hear this perspective that I challenged myself to invest in my students the way I would if they were my family. I began to think of the relationships I could create and foment over the semester and 
beyond, where I would get to know them to understand their needs and dreams. It is by so doing that I can customize my teaching and curriculum to better serve them. Moreover, this establishes a relationship of mentorship and trust. My mission has taken a transformative approach towards teaching. This is an ongoing journey I invite you all to take; it is the reason I chose to go into teaching. Teaching in times of COVID has given me the challenge and opportunity to employ these concepts in search of a more transformative social justice approach, which ultimately is so indispensable for our times. 


\section{References}

Bourdieu, Pierre. 1977. Outline of a Theory of Practice (Vol. 16). Cambridge: Cambridge University Press

Harris, Frank. 2020, April 28. YouTube. Retrieved from CORA Learning: https://www.youtube.com/watch?v=9cEWQJ32nq 
